\title{
Meningkatkan Keterampilan Writing Of Narrative Text dengan Menggunakan Teaching Materials
}

\author{
Mardiyah $^{1}$, Mustaji ${ }^{2}$, Nurmida Catherine Sitompul ${ }^{3}$ \\ ${ }^{1,3}$ Teknologi Pendidikan, Universitas PGRI Adi Buana Surabaya \\ ${ }^{2}$ Teknologi Pendidikan, Universitas Negeri Surabaya
}

\section{Edcomtech}

\section{Jurnal Kajian \\ Teknologi Pendidikan}

Volume 4, No 2, Oktober 2019

89-95

Submitted 17-04-2019

Accepted 12-08-2019

Corresponding Author

Mardiyah

mardiyahdee461@gmail.com

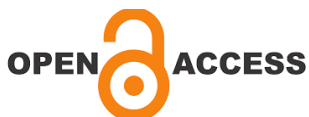

\begin{abstract}
Pengajaran menulis Narrative Text untuk siswa SMP tidak mudah karena siswa mengalami kesulitan dalam menyusun kalimat dan mengekspresikan ide dalam ketrampilan menulis. Tujuan penelitian ini menemukan efektifitas pengembangan buku bahan ajar. Pengembangan bahan ajar menggunakan model Borg and Gall dan pendekatan deskriptif kualitatif. Hasil dari reviu kelayakan produk pengembangan yaitu ahli materi (isi) bahasa Inggris sebesar $90 \%$, ahli desain pembelajaran sebesar $95 \%$. Uji coba produk menunjukkan bahwa pengembangan buku bahan ajar ini mampu meningkatkan skor hasil belajar sebesar $45 \%$ untuk perlakuan kelas eksperimen. Meskipun, kelas kontrol juga mengalami peningkatan sebesar $40 \%$. Uji coba produk kepada siswa dan guru melalui angket mendapatkan respon yang sangat menyenangkan.
\end{abstract}

Kata Kunci: Narrative Text, Writing, Teaching Materials

\begin{abstract}
The teaching of writing Narrative Texts for middle school students is not easy because students have difficulty in composing sentences and expressing ideas in writing skills. The goal of this study is to find the effectiveness of the development of teaching materials. The development of teaching materials is using the Borg and Gall development model and a qualitative descriptive approach. The results of the review of the feasibility of product development as follows the review of English material experts by $90 \%$, review of learning design experts by $95 \%$. The results of this study indicate that the development of teaching materials gives better results than not using teaching materials. There was an increase in the score of learning outcomes by $45 \%$ for the experimental class. Furthemore, The control class also increased by $40 \%$. Product trials for students and teachers through questionnaires received a very good response.
\end{abstract}

Keywords: Narrative text, writing, teaching materials, Borg and Gall 


\section{LATAR BELAKANG}

Pendidikan adalah bagian terpenting dalam kehidupan manusia untuk meningkatan kualitas kemampuan daya manusia, maka perlu dilakukan upaya pembedahan dan peningkatan kualitas layanan dalam bidang pendidikan tersebut (Margarita,2014, Rusnilawati2016, Harta 2017) melalui pendidikan insan bisa mengembangkan wawasannya dan memperoleh ilmu pengetahuan (Lanani, 2015; Mikrayanti, 2016). Didalam pendidikan ada 4 ( four) ketrampilan yang harus dimiliki oleh siswa, terutama dalam bahasa inggris

Salah satu dari 4 (four) keterampilan bahasa tersebut keterampilan berbicara dan writing termasuk dalam productive skill. Keterampilan ini termasuk produk tulisan dan ucapan siswa menjadi sebuah tujuan akhir dari proses pembelajaran. Daya berbicara dan menulis sangat dominan untuk diajarkan karena tulisan dan ujaran dapat menjadi alat untuk menbagikan ide, gagasan, dan pesan ke pembaca dengan harapan tertentu seperti yang disampaikan oleh Suparno dan Yunus (2011:1.3) menyampaikan bahwa menulis merupakan aktivitas penyebaran pesan (berkomunikasi) menggunakan bahasa tulisan sebagai alatnya. Disisi lain apa yang kita tulis dan ujaran kita dapat menyampaikan suatu cerita kepada seseorang yang tidak dekat dengan kita.

Hasil pembelajaran dan keahlian yang harus dimiliki oleh siswa dalam berbahasa adalah bisa berkomunikasi dan menyampaikan pesan kepada orang lain. Bentuk lainnya yaitu menghasilkan suatu karya yang bisa mendidik dan mengarahkan orang lain seperti menulis. Sama halnya dengan yang diutarakan oleh Tarigan (2008:3) mengungkapkan sesuatu melalui tulisan adalah "suatu keterampilan berbahasa yang digunakan untuk berkomunikasi secara tidak langsung atau bertatap muka dengan orang lain"

Berdasarkan penelitian awal diperoleh bahwa ketrampilan menulis Narrative Text siswa kelas 9 di SMPN 3 Torjun masih jauh dari kata bagus, semua ini ditunjukkan pada skor yang diperoleh. Faktor penyebabnya adalah motivasi belajar siswa yang kurang dan strategi pembelajaran yang kurang menarik, disamping itu perlengkapan yang mendukung pembelajaran bahasa Inggris di sekolah SMP Negeri 3 Torjun yang ada sangat kurang diantaranya laboratorium komputer serta buku - buku ajar yang kurang menarik buat siswa - siswi SMP Negeri 3 Torjun.

Penyebab itulah yang menimbulkan ketidak mampuan berbicara dan tulisan siswa dalam bahasa Inggris sangatlah memprihatinkan, dan juga penyebabnya adalah sebagaian besar guru kurang menguasai strategi dalam pengajaran keterampilan berbicara dan menulis disekolah tersebut. Setelah diamati oleh si peneliti dari nilai rapor dan tes praktek awal hal ini bisa membuktikan bahwa pengajaran berbicara dan menulis selama ini hanya menitik beratkan pada Grammer atau how to speak just usual, bukan membimbing siswa pada segi berbicara yang berbobot atau menghasilkan karya tulis dan kurang pandai dalam mengolah kata dalam bahasa inggris.

Guru menyampaikan materi pembelajarannya dengan ceramah. Siswa tidak dilibatkan dalam pembelajarannya sehingga pembelajarannya bersifat pasif atau berpusat pada guru (teacher-center). Hal ini juga dipengaruhi oleh kompetensi dan pengetahuan guru dalam pembelajarannya. Dengan demikian perlu adanya model, metode, strategi atau bahan pengajaran. Harapannya adalah siswa mampu mencapai tujuan pembelajaran yang diinginkan.

Ada banyak trik agar bisa menanggulangi hal diatas. Supaya harapan dapat terwujud meningkatkan keterampilan menulis materi narrative text bisa terpenuhi, sambil menyiapkan metode, strategi dan media, guru juga perlu melengkapinya dengan bahan ajar. Bahan ajar adalah alat penting yang dibutuhkan sistem pembelajaran yang bisa mempermudah siswa dalam mempelajari suatu materi. Bahan ajar disini berupa buku merupakan buku yang di pakai sebagai alat belajar di sekolah ataupun dimana saja untuk mensukseskan tujuan pembelajaran.

Untuk mencapai teori tentang karakteristik dari teks narrative bahasa Inggris setiap siswa harus tahu antara lain: tujuan umun, struktur yang di pakai dan semua hal yang mengenai kebahasaan yang sering di pakai dalam cerita atau teks narrative bahasa Inggris.

Setelah memahami penjelasan diatas 
dapat disimpulkan bahwa kewajiban seorang guru yaitu mendongkrak semangat siswa dalam mewujudkan potensi dirinya dalam menulis. Dalam hal ini guru selalu mendapat permasalahan yang sering muncul karena minimnya motivasi siswa terhadap pembelajaran bahasa Inggris dan juga rendahnya motivasi siswa dalam melaksanakan serangkaian kegiatan pembelajaran itu. Hasil wawancara awal telah menunjukkan hal tersebut. Guru hanya mengandalkan buku paket dari sekolah dan LKS. Buku mata pelajaran Bahasa Inggris yang ada pada biasanya memasukkan keterampilan berbicara, mendengarkan, menulis, dan membaca sekaligus namun belum banyak ditemukan bahan ajar yang benar-benar fokus pada salah satu keahlian. Bahan ajar lain yang dipakai intinya yang mengupas tentang keterampilan tertentu dengan memakai suatu trik tertentu belum ditemukan. Disini terlihat antara kegiatan pembelajaran di kelas serta bahan ajarnya cenderung kurang dalam memenuhi suatu ketrampilan. Untuk itu perlu adanya menggugah minat dan motivasi siswa melalui pengembangan buku bahan ajar yang menarik dan mampu memberikan panduan dalam mencapai ketrampilan tertentu.

Agar mampu menanggulangi hal itu. Dan supaya tujuan pembelajaran menulis dapat tercapai, sambil menyiapkan metode, strategi, dan media, guru juga perlu melengkapinya dengan bahan ajar. Bahan ajar adalah alat penting yang dibutuhkan sistem pembelajaran yang bisa mempermudah siswa dalam mempelajari suatu materi. Bahan ajar disini berupa buku merupakan buku yang di pakai sebagai alat belajar di sekolah ataupun dimana saja untuk mensukseskan tujuan pembelajaran. Buku bahan ajar merupakan buku yang digunakan sebagai sarana belajar di sekolah untuk menunjang program pembelajaran. Buku pelajaran menyediakan materi yang tersusun untuk keperluan pembelajaran siswa. Karena keutuhan materi dan cara menyampaikannya, buku pelajaran memberikan fasilitas bagi kegiatan belajar yang independen, baik tentang substansinya maupun caranya (Pusat Perbukuan, 2006: 3).

Bahan ajar yang berisi banyak keterampilan memang bagus, tapi itu kurang efektif karena pastinya tidak dibahas secara utuh, salah satunya keterampilan menulis. Sehingga, siswa tidak bisa memasimalkan keahliannya secara tepat. Buku ajar yang menyiapkan suatu model pembelajaran tertentu khususnya untuk mengembangkan keterampilan menulis juga belum banyak didistribusikan secara luas. Hal itu terjadi juga karena Karakteristik Pembelajarannya belum disesuaikan dengan konteks karakteristik belajar siswa SMPN 3 Torjun. Sekarang ini siswa sangat menyukai gambar - gambar yang menarik, oleh karenanya sipeneliti menyusun sebuah buku bahan ajar yang telah dilengkapi dengan gambar - gambar yang menarik test - test yang mengasah daya imajinasi dan kreatifitas siswa.

Menurut Haryono (2017) Dalam paradigma lama pembelajaran, peserta didik ditempatkan sebagai pribadi yang belum dewasa, pribadi yang pasif, objek dalam proses pembelajaran, dan juga menempatkan guru sebagai sumber kegiatan belajar. Paradigma pembelajaran ini tidak lagi memadai untuk menyiapkan Sumber Daya Manusia (SDM) abad 21 sebagai warga masyarakat global sesuai dengan pendapat Wijaya, E. Y., D.A. Sudjimat, A. Nyoto. (2016). Pembentukan Pendidikan Abad 21 sebagai harapan Pengembangan Sumber Daya Manusia Di Era Global. Jadi pada abad 21 itu pembelajajaran bukan lagi teacher centered tetapi students centered. Pada abad 21 semua sistem pembelajaran ini sangat menitik beratkan pada kreatifitas siswa serta hasil karya siswa bukan kreatifitas dan hasil karya gurunya.

Sehubungan dengan paparan tersebut diatas maka pengembang berusaha untuk melanjutkan harapan yang diinginkan bersama yaitu sebuah bahan ajar yang bisa menggali lagi kemampuan dasar siswa untuk menstimulasi daya kreatifitas siswa itu sendiri.

\section{METODE}

Model BorgandGallmenjadilandasan dalam menjalankan tahap-tahap pengembangan bahan ajar bahasa Inggris. Ada 10 tahap yang harus dilakukan berdasarkan model yang diterapkan. Untuk pengembangan bahan ajar ini, tidak semua langkah dilakukan. Hal ini disebabkan karena akan membutuhkan 
waktu yang tidak pendek. Sehingga demikian langkah-langkah yang dilakukan hanya sampai uji coba produk secara terbatas dalam lingkup satu sekolah.

\section{Prosedur Pengembangan}

Gambar 1 mengillustrasikan langkahlangkah yang dilakukan dalam pengembangan dengan menggunakan model Borg and Gall. Alur pelaksanaan pengembangan dengan model ini yaitu alur maju, tidak ada langkah kembali pada saat terjadi ketidaksesuaian atau permasalahan pada pelaksanaan langkah.

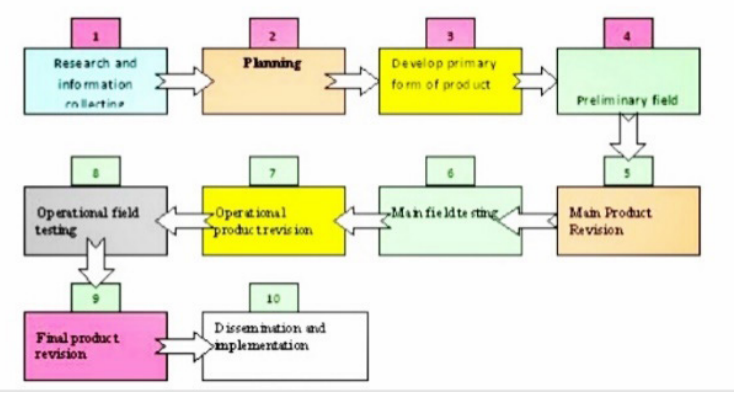

Gambar 1 Model pengembangan Borg and

Gall (Sumber: Borg and Gall, 1983:775)

\section{HASIL DAN PEMBAHASAN}

Hasil langkah pertama yaitu Research and information collecting/Tahap penelitian dan pengumpulan data, meliputi: pengamatan atau observasi kelas dan persiapan laporan awal melalui quisioner. Penelitian awal atau analisis kebutuhan sangat penting dilakukan guna memperoleh informasi awal untuk melakukan pengembangan. Ini bisa dilakukan misalnya melalui pengamatan kelas untuk melihat kondisi fakta dilapangan. Dalam observasi tersebut. Pengembang dapat gambaran tentang kebutuhan design pembelajaran yang akan dikembangkan. Gambaran datanya sebagai berikut subyek penelitian merupakan anak berusia 15-16 tahun siswa SMP Negeri 3 Torjun Sampang Madura. Yang akan dijadikan tempat untuk melakukan kegiatan pembelajaran. menganalisa kebutuhan anak yang masih berusia 15- 16 tahun dengan kondisi tempat, sarana dan prasarana yang tidak lengkap serta buku - buku ajar yang kurang begitu attraktif buat siswa yang berusia seperti mereka. Tidak ada lab yang bisa mendukung proses pembelajaran di sekolah tersebut. Dari angket yang sudah disebarkan dapat ditarik kesimpulan bahwa memang tidak ada lab yang mendukung dalam proses belajar dan pembelajaran di sekolah tersebut.

Langkah berikutnya adalah planning (melakukan perencanaan). Pada langkah ini di SMP Negeri 3 Torjun melakukan analisis terhadap pembelajaran yang terjadi selama ini di SMP Negeri 3 Torjun. Sebenarnya didalam proses pembelajaran sudah dilaksanakan dengan menggunakan Bahan Ajar. Namun hasilnyapun tidak begitu maksimal. Pada tahap ini peneliti melakukan pembuatan bahan ajar yang diformulasikan dengan jiwa dan kemampuan sarana serta prasarana yang dimiliki oleh siswa itu sendiri untuk meningkatkan kreativitas dan sikap kerjasama siswa dalam belajar. Namun masih belum begitu sempurna.

Langkah ketiga adalah Develop primary form of product (pengembangan draf produk). Pengembangan draf produk bahan ajar ini dilakukan setelah direvisi dari tim ahli isi dan tim ahli media dengan tetap melihat karakter dan kebutuhan siswa. Produk yang dihasilkan kemudian di uji cobakan secara lengkap meliputi beberapa tahapan antara lain reviu Ahli Materi atau ahli bidang isi Bahasa Inggris ali materi dalam hal ini tentunya adalah orangorang yang memahami tentang pembelajaran bahasa Inggris pada pengembang ini ahli materi adalah satu dosen bergelar doktor pendidikan bahasa inngris reviu ini dilaksanakan untuk memperoleh data yang berupa penilaian pendapat maupun saran terhadap pengembangan isi materi ini. Ahli materi dalam hal ini adalah seorang dosen S1 bahasa Inggris Universitas ADIBUANA Surabaya. Data yang diperoleh dari pengisian angket yang diberikan adalah dilihat dari kelayakan isi, gambar - gambar, warna, serta soal - soal yang disajikan terhadap buku bahan ajar menulis narrative text adalah $90 \%$. Reviu ahli desain pembelajaran reviu pada tahap ini dilaksanakan untuk memperoleh data yang berupa penilaian opini maupun anjuran terhadap pengembangan bahan ajar ini dan komponen-komponen desain pengembangan, dan dari penilaian pendapat yang diperoleh dari reviu ahli desain $95 \%$ menilai bagus dan cocok untuk berikutnya 
dipakai dalam pelaksanaan pembelajaran di SMP tanpa revisi.

Langkah keempat yaitu Preliminary field (uji coba lapangan awal) adalah uji coba lapangan awal, hal ini dilaksanakan untuk mengetahui respon awal siswa. Pada langkah ini dilakukan dengan tes awal pada satu siswa kelas 9A. Dari hasil tes itu bisa dilihat dari nilainya yang belum memuaskan.

Langkah kelima yaitu Main product revision (Merevisi hasil uji coba) yaitu melakukan revisi atas kekurangan bahan ajar yang telah direvisi agar bisa diformulasikan dengan kemampuan dan keinginan siswa. Gambar 2 memperlihatkan sampul buku yang sudah direvisi berdasarkan saran dan anjuran dari ahli media maupun ahli materi.

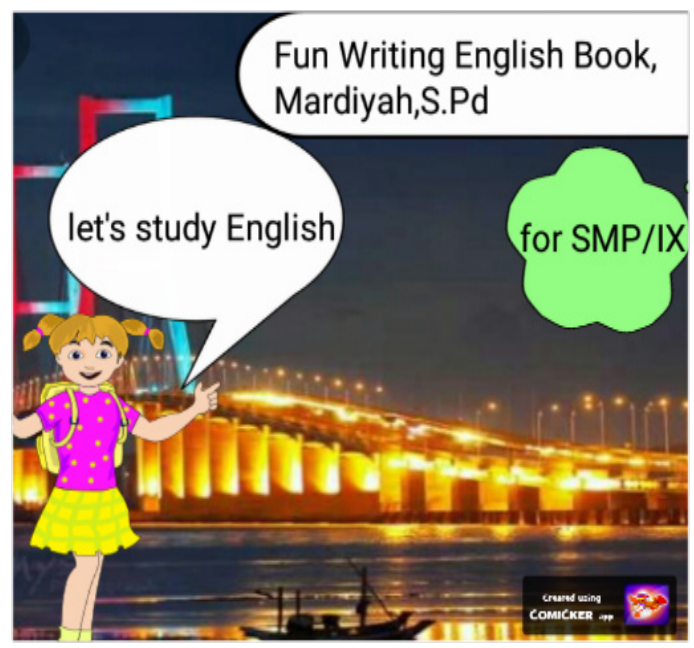

Gambar 2 sampul buku yang sudah direvisi

Langkah keenam yaitu Main field testing (uji coba lapangan) uji coba lapangan dengan menggunakan bahan ajar yang telah dikreasikan oleh pengembang. Uji coba dilakukan untuk melihat sejauh mana pengembangan buku bahan ajar ini menarik dan dapat diimplementasikan dalam proses pengajaran. Selanjutnya proses pengajaran selesai siswa mengisi quisioner dan memberikan sarat terkait dengan produk pengembangan setelah digunakan dalam proses pembelajaran. uji lapangan dilakukan di SMP Negeri 3 Torjun Sampang Madura kelas IXA

Langkah ketujuh adalah Operational product revision (penyempurnaan produk hasil uji lapangan) sambil melengkapi dengan latihan - latihan dimana mengkombinasikan soal - soal dan gambar - gambar. Dimana siswa harus lebih aktif dalam pembelajaran ini. Karena sistem pembelajaran ini adalah student centered.dan siswa diharapkan untuk bisa menyampaikan makna tersirat dalam suatu cerita. Gambar 3 memperlihatkan soalsoal untuk menggali daya pikir siswa dengan dilatarbelakangi gambar yang memotivasi siswa dalam mengerjakan soal.

\section{Answer the questions based on the story! \\ > Were her stepmother and her stepsisters friendly? \\ When did the story happen? \\ Why did her stepsisters hate Cinderella?

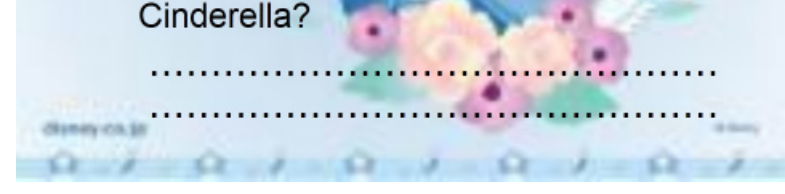 \\ Gambar 3 soal - soal untuk menggali daya pikir siswa \\ Langkah kedelapan Operational field testing (uji pelaksanaan lapangan) yang dilakukan pada kelas 9A SMP Negeri 3 Torjun, Sampang Madura dan dari hasil nilai uji pelaksanaan lapangan akan menjadi tolok ukur kemajuan peningkatan dengan bahan ajar yang telah dibuat.}

Tabel 1 Hasil analisis nilai siswa kelas 9A

\begin{tabular}{llrccc}
\multicolumn{7}{c}{ Group Statistics } \\
\hline \hline media & $N$ & Mean & $\begin{array}{c}\text { Std. } \\
\text { Deviation }\end{array}$ & $\begin{array}{c}\text { Std. Error } \\
\text { Mean }\end{array}$ \\
\hline hasil & tanpa & 24 & 37,7083 & 12,93623 & 2,64060 \\
& medja & & & \\
& medla buku & 24 & 82,7083 & 13,75082 & 2,80688 \\
\hline \hline
\end{tabular}

Dari tabel 1 dapat disimpulkan bahwa ada pengaruh pada hasil ketika siswa menggunakan media bahan ajar, tertera ada nilai 82,7083 yang bermakna ada pengaruh antara media buku dengan hasil belajar siswa kelas 9A. Yang bisa ditarik kesimpulan dari data tersebut dengan adanya media buku dapat meningkatkan hasil pembelajaran siswa.

Dari temuan penelitian pengembangan bahan ajar memiliki gambar dan warna yang 
beragam dan menarik hati sehingga bisa menarik perhatian siswa dan bisa memotivasi siswa dalam belajar.

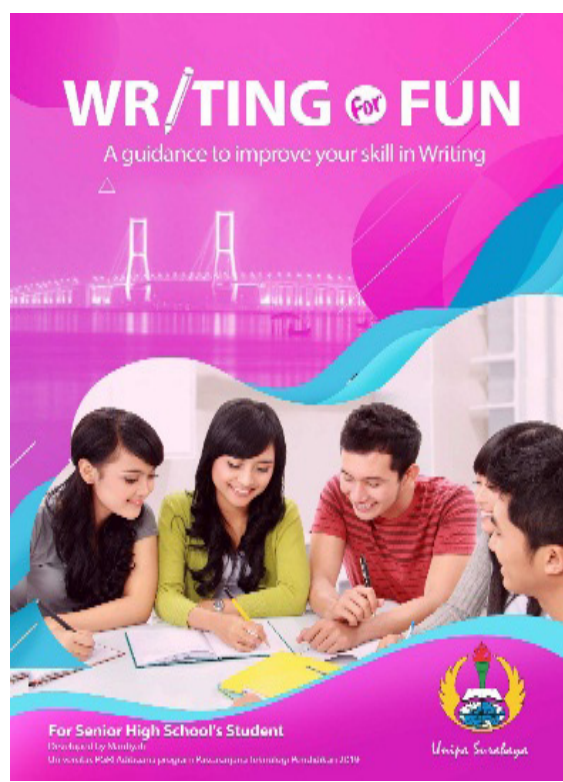

Gambar 4 halaman sampul revisi terakhir

Langkah ke sembilan yaitu Final product revision ( penyempurnaan produk akhir ) adalah revisi akhir produk ini dilaksanakan untuk memperbaiki kelemahan bahan ajar yang telah dikreasikan supaya mampu menyempurnakan produk. Gambar 4 memperlihatkan halaman sampul yang yang telah direvisi berdasarkan evaluasi dari uji coba lapangan. Pengembangan soal juga diperbaiki dan dikembangkan dengan menitikberatkan pada kreatifitas menulis siswa seperti terlihat pada gambar 5 .

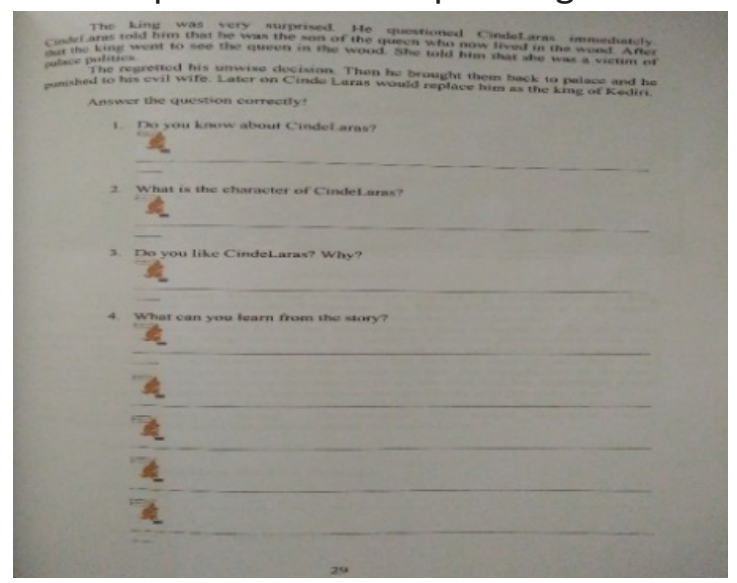

Gambar 5 soal menitik beratkan pada kreatifitas menulis

Langkah ke sepuluh atau langkah terakhir dari model pengembangan Borg and Gall yaitu Dissemination and implementation (diseminasi dan implementasi) adalah menyebarkan produk buku bahan ajar adalah dengan membagikan kepada seluruh siswa SMP Negeri 3 Torjun. Buku bahan ajar yang telah dibuat sedang dalam proses mendapatkan ISBN (International Standard Book Number).

\begin{tabular}{llrcrc}
\multicolumn{6}{c}{ Group Statistios } \\
\hline & media & N & Mean & Deviation & St. ETor \\
Mean & \\
\hline a & tanpa media & 24 & 37,5000 & 13,18761 & 2,69191 \\
& media buku & 24 & 78,1250 & 12,05175 & 2,46005 \\
\hline
\end{tabular}

Tabel 2 Hasil analisis nilai murid kelas 9B

Result pada tahapan ini bisa digambarkan bahwa pengembangan bahan ajar ini mampu menghasilkan sesuatu hal yang maksimal dibanding tidak memakai bahan ajar, hal ini ditunjukkan nilai siswa yang menunjukkan peningkatan hasil belajar dari nilai 37.7083 menjadi 82.7083 untuk kelas $9 A$ jadi peningkatannya ada $45 \%$. Siswa kelas 9B hasil sebelumnya adalah 37.5000 menjadi meningkat 78.1250 bila dikalkulasi peningkatannya ada $40.63 \%$, seperti yang ditunjukkan pada tabel 2. Result reviu kepantasan produk pengembangan sebagai berikut: 1) reviu ahli materi bahasa Inggris sebesar $90 \%$, reviu ahli desain pembelajaran sebesar 95\%. 2) trial produk terhadap murid dan guru dengan menggunakan angket memperoleh tanggapan yang sangat memuaskan.

\section{SIMPULAN}

Setelah dilakukan penelitian dan pengambilan data serta dilakukan pembahasan maka kesimpulan bisa diperoleh dari penelitian pengembangan ini bahwa buku bahan ajar ini layak untuk dipakai dan dimanfaatkan dalam proses pembelajaran dan pengembangan ketrampilan siswa dalam menulis narrative text.

\section{DAFTAR PUSTAKA}

Harta, k I.(2017) pengembangan prototipe ECG Boiler sebagai Media pembelajaran Prakarya dan kewirausahaan untuk Materi Teknologi Tepat Guna kelas XI MIA SMA Negeri 4 Singaraja tahun 
ajaran 2016/2017. Jurnal Pendidikan Teknologi dan Kejuruan, 14 (2), 178-187 Haryono (2017) Teknologi Pendidikan Abad 21, Banjarmasin: Prosiding Seminar Nasional Teknologi Pendidikan, 15 Juli 2017, hal. $425-436$

Lanani K (2015) Efektivitas Pembelajaran Kooperatif ditinjau Dari Peningkatan Kemampuan Penalaran Logis Matematis Siswa, Infinity: Jurnal IImiah Program Studi Matematika, 4 (2), 140-151

Margarita . Ld. (2014) . Penggunaan Media Animasi Macromedia Flash untuk Meningkatkan Kualitas Pembelajaran IPA siswa Tunarungu kelas II SDLB. Jurnal P3LB. 1 (2), 137-139

Gall, M. D., Gall, J. P., \& Borg, W. R. (2003). Educational Research an Introduction, Seventh Editions. University of Oregon. United State of America.

Mikrayanti (2016) Meningkatkan kemampuan Penalaran matematis melalui Pembelajaran Berbasis Masalah Suska journal of Mathematics Education, 2 (2), $97-102$

Rusnilawati R. (2016) Pengembangan Perangkat Pembelajaran matematika Bercirikan Active Knowledge Sharing Dengan Pendekatan Stifikasi kelas VIII. Jurnal Riset Pendidikan Matematika 3 (2), $246-258$

Suparno, dan Yunus 2011 Keterampilan menulis. Jakarta: Universitas Terbuka

Tarigan. H. G. 2008 menulis sebagai satu keterampilan berbahasa. Bandung: Angsara

Wijaya, E. Y., D.A. Sudjimat, A. Nyoto. (2016). Transformasi Pendidikan Abad 21 sebagai Tuntutan Pengembangan Sumber Daya Manusia Di Era Global, Malang: Prosiding Seminar Nasional Pendidikan Matema-tika 2016 Universitas Kanjuruhan Malang, Vol 1 Tahun 2016, hal. 263 - 278. 